\title{
Effects of Water Depth on the Growth of the Submerged Macrophytes Vallisneria natans and Hydrilla verticillata: Implications for Water Level Management
}

\author{
Qisheng Li, Yanqing Han, Kunquan Chen, Xiaolong Huang ${ }^{D}$, Kuanyi Li and Hu He *D \\ State Key Laboratory of Lake Science and Environment, Nanjing Institute of Geography and Limnology, \\ Chinese Academy of Sciences, Nanjing 210008, China; liqisheng515@163.com (Q.L.); \\ hanyanqing18@mails.ucas.ac.cn (Y.H.); chenkq816@163.com (K.C.); xlhuang@niglas.ac.cn (X.H.); \\ kyli@niglas.ac.cn (K.L.) \\ * Correspondence: hehu@niglas.ac.cn; Tel.: +86-25-8688-2237
}

check for updates

Citation: Li, Q.; Han, Y.; Chen, K.; Huang, X.; Li, K.; He, H. Effects of Water Depth on the Growth of the Submerged Macrophytes Vallisneria natans and Hydrilla verticillata: Implications for Water Level Management. Water 2021, 13, 2590. https://doi.org/10.3390/w13182590

Academic Editors: Emeritus William D. Taylor and Xiufeng Zhang

Received: 30 July 2021

Accepted: 17 September 2021

Published: 19 September 2021

Publisher's Note: MDPI stays neutral with regard to jurisdictional claims in published maps and institutional affiliations.

Copyright: (c) 2021 by the authors. Licensee MDPI, Basel, Switzerland. This article is an open access article distributed under the terms and conditions of the Creative Commons Attribution (CC BY) license (https:// creativecommons.org/licenses/by/ $4.0 /)$.

\begin{abstract}
Water level is one of the most important factors affecting the growth of submerged macrophytes in aquatic ecosystems. The rosette plant Vallisneria natans and the erect plant Hydrilla verticillata are two common submerged macrophytes in lakes of the middle and lower reaches of the Yangtze River, China. How water level fluctuations affect their growth and competition is still unknown. In this study, three water depths $(50 \mathrm{~cm}, 150 \mathrm{~cm}$, and $250 \mathrm{~cm}$ ) were established to explore the responses in growth and competitive patterns of the two plant species to water depth under mixed planting conditions. The results show that, compared with shallow water conditions $(50 \mathrm{~cm})$, the growth of both submerged macrophytes was severely suppressed in deep water depth $(250 \mathrm{~cm})$, while only $V$. natans was inhibited under intermediate water depth $(150 \mathrm{~cm})$. Moreover, the ratio of biomass of $V$. natans to $H$. verticillata gradually increased with increasing water depth, indicating that deep water enhanced the competitive advantage of $V$. natans over H.verticillata. Morphological adaptation of the two submerged macrophytes to water depth was different. With increasing water depth, H. verticillata increased its height, at the cost of reduced plant numbers to adapt to poor light conditions. A similar strategy was also observed in $V$. natans, when water depth increased from $50 \mathrm{~cm}$ to $150 \mathrm{~cm}$. However, both the plant height and number were reduced at deep water depth $(250 \mathrm{~cm})$. Our study suggests that water level reduction in lake restoration efforts could increase the total biomass of submerged macrophytes, but the domination of key plants, such as V. natans, may decrease.
\end{abstract}

Keywords: lake restoration; morphological response; interspecific competition; light attenuation

\section{Introduction}

In freshwater lakes, submerged macrophytes are related to various biogenic elements (N, P, S, etc.) in the water body, and they are the shapers of lake ecosystem structure and the maintainers of lake ecosystem function [1,2]. For example, studies of temperate lakes have shown that submerged macrophytes can influence the structure of food webs by providing spawning grounds and habitats for fish [3] and supplying abundant food and shelter for zooplankton and invertebrates [4]. Submerged macrophytes can also promote the settlement of suspended particulate matter in water [5] and inhibit the growth of phytoplankton through allelopathy and nutrient competition [6].

Water level is one of the main factors affecting the growth and distribution of submerged macrophytes in shallow lakes [7-10]. Within a specific range, a decrease in water level will increase the light intensity in the water, thus increasing the biomass and diversity of submerged macrophytes [11]. For instance, in Lake Okeechobee, USA, the lake depth in 2000 (2.8 3.7 m) was significantly lower than that in 1999 (4.0 5.2 m). Simultaneously, the biomass of submerged macrophytes in the lake increased rapidly from $5 \mathrm{~g} \mathrm{~m}^{-2}$ (dry weight) in 1999 to $12 \mathrm{~g} \mathrm{~m}^{-2}$ in 2000, and the distribution area expanded from $15 \mathrm{~km}^{2}$ in 
1999 to $180 \mathrm{~km}^{2}$ [12]. Geest investigated 100 floodplain lakes in the lower Rhine River and found that the species richness of submerged macrophytes was significantly positively correlated with the proportion of certain water levels (the ratio of the exposed lake floor area after water depth decreased in October to the lake floor area during the high-water season in July), indicating that the decrease in water depth was conducive to the increase in submerged macrophyte diversity [13]. In lake restoration in China, decreasing water level was also often used to rapidly improve light conditions, thus creating conditions for the recovery of submerged macrophytes [14-16]. In addition, the change in water depth may also change the interspecific relationships and community structure of submerged macrophytes due to the differences in photosynthetic characteristics, morphological plasticity and reproductive strategies among different plant species [17]. For example, Gao found that the biomass and relative growth rate of Myriophyllum spicatum and Potamogeton malaianus, canopy-forming plants, increased with increasing water depth (from 2.6 to $3.8 \mathrm{~m}$ ), while the dominance of Hydrilla verticillata, which is an erect plant, decreased significantly [18].

Vallisneria natans and $H$. verticillata are common submerged macrophyte species in shallow lakes in China, and are also widely used as pioneer plant species in lake restoration. $V$. natans can tolerate a certain degree of low light in turbid waters due to its low lightcompensation point, while $H$. verticillata tends to dominate in high-transparency waters due to its high light-compensation point [18]. There may be solid interspecific competition between the two submerged macrophytes in natural water bodies. Most of the previous studies focused on the response of a single submerged macrophyte to water level/depth or light at the population level $[18,19]$, but the effect of water depth on the competitive abilities of two submerged macrophytes has rarely been reported for water bodies where the two species coexist. In this study, outdoor mesocosm experiments were conducted to investigate the effects of water depth on the growth of the two submerged macrophytes. It is assumed that an increase in water depth will decrease the biomass of both submerged macrophytes but increase the domination of $V$. natans due to its low light-compensation point.

\section{Materials and Methods}

\subsection{Experimental Design}

The outdoor mesocosm experiment was conducted in an experimental pool $(3 \mathrm{~m}$ in length, $3 \mathrm{~m}$ in width, and $2.5 \mathrm{~m}$ in height) at Taihu Laboratory for Lake Ecosystem Research $\left(31^{\circ} 30^{\prime} \mathrm{N}, 120^{\circ} 30^{\prime} \mathrm{E}\right)$, located in Meiliang Bay on the northern edge of Lake Taihu, China. The mesocosm experiment lasted 49 days, from 22 August to 10 October 2018. Young similar-sized seedlings of $V$. natans and $H$. verticillata with good growth and uniform color were collected from a nearby river one week before the experiment. They were precultivated with lake water and lake sediment in plastic bins outdoors. Before the experiment began, the pool was cleaned and filled with lake water, which was taken from Meiliang Bay of Taihu Lake, filtered through a $64 \mu \mathrm{m}$ plankton net to remove planktonic crustaceans, and slowly injected.

On the day of the experiment, the mixed lake sediment $(10 \mathrm{~cm})$ was placed into plastic containers (height $16 \mathrm{~cm}$, the diameter of upper and lower bottom $41 \mathrm{~cm}$ and $33 \mathrm{~cm}$, respectively), and then 15 uniform $V$. natans (each with approximately 5-6 bright green leaves, a length of $15 \pm 0.5 \mathrm{~cm}$ ) and $H$. verticillata (a length of $15 \pm 0.5 \mathrm{~cm}$ ) plants were transplanted into each mesocosm. Sediment (TN: $2.04 \pm 0.06 \mathrm{mg} \mathrm{g}^{-1}$; TP: $0.32 \pm 0.01 \mathrm{mg} \mathrm{g}^{-1}$ ) was also collected from Meiliang Bay of Taihu Lake, filtered with a screen (mesh size: $1.7 \mathrm{~mm}$ ) to remove snails and shellfish, mixed, and added. The plastic mesocosm was quickly added to the experimental pool. The initial total wet weight of $V$. natans was $21.82 \pm 0.30 \mathrm{~g}$, and the density was approximately $170 \mathrm{~g} \mathrm{~m}^{-2}$, while the initial total wet weight of $H$. verticillata was $8.89 \pm 0.17 \mathrm{~g}$, and the density was approximately $68 \mathrm{~g} \mathrm{~m}^{-2}$. The density of the two submerged macrophytes was in the range of the summer submerged macrophyte density in West Taihu Lake [20]. Three water depth gradients were set up in the experiment, which were named the shallow water depth group $(50 \mathrm{~cm})$, intermediate water depth group $(150 \mathrm{~cm})$, and deep water depth group $(250 \mathrm{~cm})$. There were four replicates in each gradient 
and 12 experimental units in total. The three water depths corresponded well with the range of annual fluctuations in some shallow lakes in the middle and lower reaches of the Yangtze River.

\subsection{Sampling and Analytical Methods}

Water samples were collected weekly during the experiment. Prior to water sampling, the light intensity in each mesocosm was measured in situ at four depths $(0 \mathrm{~cm}, 50 \mathrm{~cm}$, $150 \mathrm{~cm}$, and $250 \mathrm{~cm}$ ) using an underwater digital luxmeter (ZDS-10W, Yueci Electronic Technology Co., Ltd., Shanghai, China).

Water samples $(5 \mathrm{~L})$ were also collected weekly from each mesocosm using an acrylic tube sampler. The samples were analyzed for nutrient contents and chlorophyll $a(\mathrm{Chl}-a)$. Unfiltered water samples were analyzed for total phosphorus (TP) and total nitrogen (TN) by colorimetry after digestion with $\mathrm{K}_{2} \mathrm{~S}_{2} \mathrm{O}_{8}$ and $\mathrm{NaOH}$ solutions. The same methods were used for analyzing total dissolved phosphorus (TDP) and total dissolved nitrogen (TDN), with the exception of the samples being filtered before analysis [21] (Jin and Tu 1990). Chl- $a$ was determined from filtered matter retained on a glass microfiber filter (Whatman GF/C International Ltd., Maidstone, England) and extracted in a 90\% acetone/water solution over $24 \mathrm{~h}$, after which the concentrations were measured using a spectrophotometer (UV-2450, Shimadzu Co., Ltd., Kyoto, Japan) [22].

All samples of $V$. natans and $H$. verticillata were collected at the end of the experiment (10 October) and thoroughly rinsed with running water to estimate the total wet biomass and the mean number of plants in each mesocosm. To ensure that the water content of the wet biomass was consistent across samples and time, before weighing, the washed plants were allowed to drain on the absorbent paper for $10 \mathrm{~min}$. Afterward, the plant materials were gently pressed on the paper until no water appeared on the paper. Then, the biomass (wet weight/area) and relative growth rate (RGR) were calculated; the RGR was estimated using the following equation:

$$
\operatorname{RGR}\left(\mathrm{mg} \mathrm{g}^{-1} \mathrm{~d}^{-1}\right)=\ln \left(\mathrm{W}_{\mathrm{f}} / \mathrm{W}_{\mathrm{i}}\right) / \mathrm{D},
$$

where $W_{\mathrm{f}}(\mathrm{g})$ and $\mathrm{W}_{\mathrm{i}}(\mathrm{g})$ are the final and initial total wet weights of plants in each mesocosm, respectively, and $\mathrm{D}$ is days [23].

In addition, five $V$. natans and five $H$. verticillata were randomly selected from each mesocosm to measure the plant numbers and plant height of $V$. natans and the branch number and plant height of $H$. verticillata. Finally, the average value of five plants was used to represent the morphological data of plants in the experimental mesocosm.

One-way analysis of variance (one-way ANOVA) was used to reveal the effects of water depth on biomass and morphological indicators of $V$. natans and $H$. verticillata at the end of the experiment. Data were $\log _{10} x$ transformed to meet the requirements of normal distribution and homogeneity of variance. All comparisons were conducted using the statistical package SPSS, version 19.0, and all figures were plotted by Prism 7.0.

\section{Results}

\subsection{Water Physical and Chemical Parameters}

Underwater light conditions decreased with increasing in water depth (Table 1). The effects of water depth on nutrient concentrations and chlorophyll $a$ concentrations (Chl- $a$ ) were apparently minor in our experiment (Table 1). 
Table 1. Changes in light (light intensity of target depth to water surface), total nitrogen (TN), total phosphorus (TP), total dissolved nitrogen (TDN), total dissolved phosphorus (TDP), and chlorophyll $a$ (Chl- $a$ ) concentrations during the experiment.

\begin{tabular}{|c|c|c|c|c|c|c|c|c|c|}
\hline & \multicolumn{3}{|c|}{ Shallow } & \multicolumn{3}{|c|}{ Intermediate } & \multicolumn{3}{|c|}{ Deep } \\
\hline & Max & Min & Average & Max & Min & Average & Max & Min & Average \\
\hline Light (target depth: surface) & 0.437 & 0.181 & 0.304 & 0.132 & 0.029 & 0.075 & 0.048 & 0.005 & 0.023 \\
\hline $\mathrm{TN}\left(\mathrm{mg} \mathrm{L}^{-1}\right)$ & 1.60 & 1.04 & 1.26 & 1.36 & 1.06 & 1.21 & 1.41 & 1.04 & 1.21 \\
\hline $\mathrm{TP}\left(\mu \mathrm{g} \mathrm{L}^{-1}\right)$ & 70 & 42 & 56 & 67 & 44 & 57 & 76 & 47 & 60 \\
\hline $\operatorname{TDN}\left(\mathrm{mg} \mathrm{L}^{-1}\right)$ & 0.96 & 0.78 & 0.87 & 0.95 & 0.79 & 0.88 & 0.94 & 0.78 & 0.87 \\
\hline $\operatorname{TDP}\left(\mu \mathrm{g} \mathrm{L}^{-1}\right)$ & 37 & 20 & 28 & 37 & 21 & 28 & 39 & 20 & 28 \\
\hline Chl- $a\left(\mu \mathrm{g} \mathrm{L}^{-1}\right)$ & 28 & 5 & 17 & 25 & 6 & 15 & 27 & 6 & 17 \\
\hline
\end{tabular}

\subsection{Growth of Submerged Macrophytes}

Along with the increase in water depth, we found significant declining trends in biomass, RGR, and plant numbers of $V$. natans (Table 2; Figure 1a-c). Water depth also significantly affected the height of $V$. natans (Table 2; Figure 1d). The height of $V$. natans was significantly higher in the intermediate water depth group than in the shallow and deep water depth groups. The latter resulted in the lowest height (Figure 1d).

Table 2. One-way ANOVA results of the growth and morphological indices of both submerged macrophytes among different water depths.

\begin{tabular}{ccccc}
\hline & Variables & F & Df & $p$ \\
\hline \multirow{4}{*}{ V. natans } & Biomass & 134.48 & 2.00 & $<0.001$ \\
& RGR & 28.76 & 2.00 & $<0.001$ \\
& Numbers & 88.94 & 2.00 & $<0.001$ \\
& Height & 124.57 & 2.00 & $<0.001$ \\
\hline \multirow{3}{*}{ H. verticillata } & Biomass & 256.56 & 2.00 & $<0.001$ \\
& RGR & 31.93 & 2.00 & $<0.001$ \\
& Numbers & 657.42 & 2.00 & $<0.001$ \\
Total & Height & 224.94 & 2.00 & $<0.001$ \\
\hline \multirow{2}{*}{ Total biomass } & 505.88 & 2.00 & $<0.001$ \\
& V. natans: H. verticillata & 35.21 & 2.00 & $<0.001$ \\
\hline
\end{tabular}
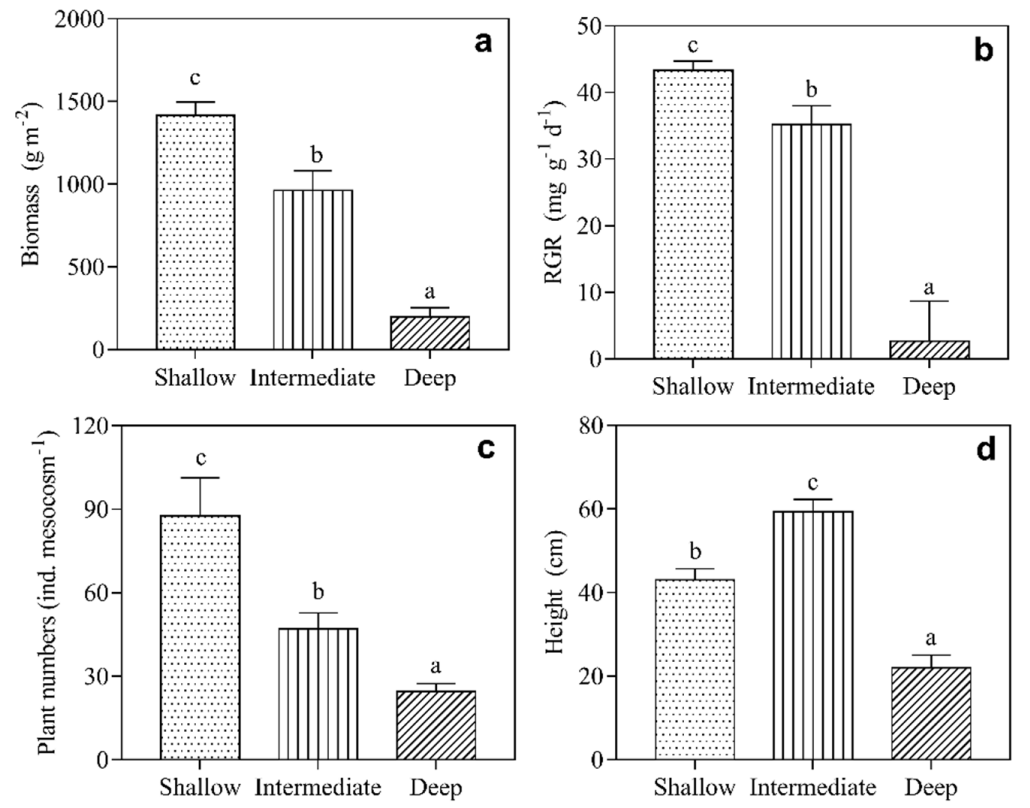

Figure 1. Comparisons of (a) biomass $\left(\mathrm{g} \mathrm{m}^{-2}\right)$, (b) RGR $\left(\mathrm{mg} \mathrm{g}^{-1} \mathrm{~d}^{-1}\right)$, (c) plant numbers (ind. mesocosm $\left.\mathrm{m}^{-1}\right)$, and $(\mathbf{d})$ plant height $(\mathrm{cm})$ of $V$. natans among three water depth groups. Values represent mean $\pm \mathrm{SD}(\mathrm{n}=4)$. Means with different letters are significantly different $(p<0.05)$. 
Water depth significantly affected the biomass, RGR, and plant branch numbers of $H$. verticillata (Table 2; Figure $2 \mathrm{a}-\mathrm{c}$ ). The biomass, RGR, and plant branch numbers were notably lower in the deep water group than in the shallow and intermediate water groups. However, there was no significant difference between shallow and intermediate water depths (Table 2; Figure 2a-c). In addition, water depth also notably affected the height of $H$. verticillata. As the water depth increased, the height of $H$. verticillata increased (Table 2; Figure 2d).
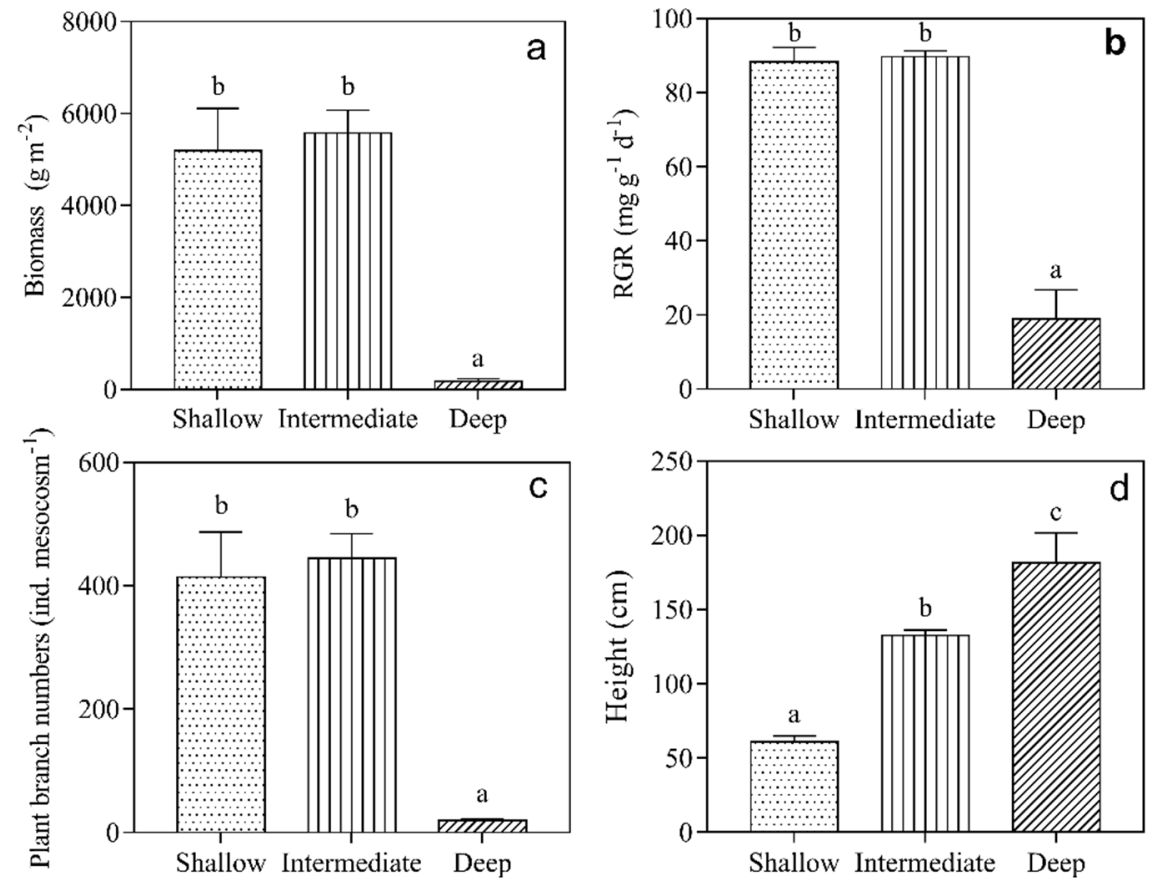

Figure 2. Comparisons of (a) biomass $\left(\mathrm{g} \mathrm{m}^{-2}\right)$, (b) RGR $\left(\mathrm{mg} \mathrm{g}^{-1} \mathrm{~d}^{-1}\right)$, (c) plant branch numbers (ind. mesocosm $\left.{ }^{-1}\right)$, and (d) plant height $(\mathrm{cm})$ of $H$. verticillata among three water depth groups. Values represent mean $\pm \mathrm{SD}(\mathrm{n}=4)$. Means with different letters are significantly different $(p<0.05)$.

Water depth also prominently affected the total biomass and the biomass ratio of $V$. natans to $H$. verticillata (Table 2; Figure 3). The total biomass of $V$. natans to $H$. verticillata was significantly lower in deep water than in the shallow and intermediate water depth groups. However, there were no significant differences between the shallow and intermediate water groups (Table 2; Figure 3). At the same time, the biomass ratio of V. natans to $H$. verticillata in deep water was significantly higher than that at shallow and intermediate water depths. There were no significant differences between the shallow and intermediate water depth groups (Table 2; Figure 3). 


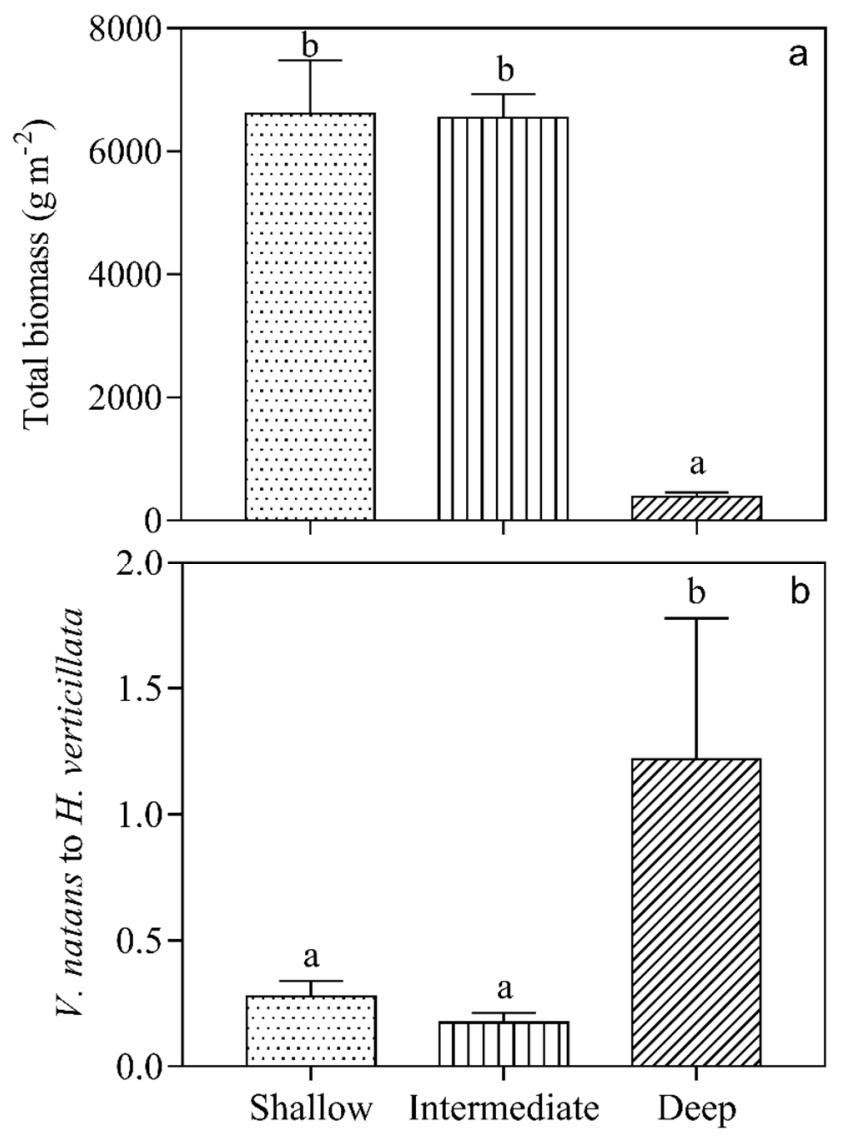

Figure 3. Comparisons of (a) total macrophyte biomass $\left(\mathrm{g} \mathrm{m}^{-2}\right)$ and (b) biomass ratio of $V$. natans to $H$. verticillata among the three water depth groups. Values represent mean $\pm \operatorname{SD}(n=4)$. Means with different letters are significantly different $(p<0.05)$.

\section{Discussion}

By mixing plantings of $V$. natans and $H$. verticillata, our study aimed to explore the effect of water level fluctuations on the growth of these two submerged macrophytes and their competition. As expected, we found that increased water depth (from $50 \mathrm{~cm}$ to $250 \mathrm{~cm}$ ) significantly reduced the total biomass of submerged macrophytes due to changes in light penetration, which were in line with most mesocosm experiments and field investigations [24-26].

Laboratory studies have found that $V$. natans has a low light-compensation point relative to other submerged macrophyte species, which causes $V$. natans to often grow at greater depths in lakes [27]. In our study, we found that, with the increase in water depth, the biomass and RGR of $V$. natans plants showed a decreasing trend (Figure 1a-c). Similar results were also found in mesocosm experiments by Li et al. (2019), Diao et al. (2017), and $\mathrm{Fu}$ et al. (2012), indicating that increased water depths would significantly suppress $V$. natans growth in spite of its low light-compensation point $[24,28,29]$. In our study, we found that plant numbers of $V$. natans decreased significantly with increasing water depth, while plant height was higher in the intermediate water depth treatment than in the shallow water depth treatment (Figure 1c,d). This result is similar that of Xiao et al. (2007), who found that, with good light conditions, $V$. natans occupied more space by increasing the length of stolons for clonal reproduction. Under poor light conditions, $V$. natans obtained sufficient light by vertical expansion, such as increasing plant height, while horizontal proliferation decreased [30]. However, in our study, both plant numbers and plant height were lowest in the deep water, suggesting that both horizontal proliferation and vertical growth were inhibited when light was extremely low. In this case, $V$. natans may allocate more resources to the below-ground part, e.g., roots and rhizome $[9,31]$. 
As an erect plant, $H$. verticillata has a higher light-compensation point than $V$. natans, and is thought to be less light tolerant in lakes [27]. Additionally, our results support this view, as we found that both biomass and RGR in deep water were the lowest among three water depth groups (Figure 2). In our study, light intensity in deep water was generally below $1000 \mathrm{~lx}$ and low light intensity limited the growth of $H$. verticillata. Previous studies suggested that $H$. verticillata adapted to low-light conditions by increasing their height and to high-light conditions by forming a canopy, reducing the damage to the lower part of the plant [32]. This phenomenon was also observed in our study; that is, in the shallow and intermediate water depth groups, $H$. verticillata formed a relatively closed canopy by reducing plant height and increasing the number of branches. In the deep water depth group, it showed increased plant height and reduced numbers of ramets to cope with the low light intensity. Mesocosm experiments conducted by Wu et al. (2011) also showed that within the range of $0.5-2.0 \mathrm{~m}$, the plant height of $H$. verticillata was negatively and linearly related to water depth, similar to the results of this study [33].

Our results also show that the changes in water depth affected the competition patterns of the two submerged macrophytes, since the proportion of $V$. natans among the total biomass of the submerged macrophytes increased with increasing water depth, while H. verticillata showed the opposite trend (Figure 3). The results are consistent with the photosynthetic characteristics and water depth distribution of the two plants in shallow lakes [34-36], suggesting that increased light penetration would favor the dominance of erect plant species. This may have implications in lake restoration, where water level is often adjusted to increase the light conditions for the colonization of submerged macrophytes [37]. Our results suggest that, although this change in water level/depth may increase the total biomass of submerged macrophytes, it may also cause a high dominance of erect-type H. verticillata, while key populations such as Vallisneria spinulosa may be difficult to develop [15]. Therefore, the photosynthetic characteristics of submerged macrophytes should be fully considered in the context of water level regulations to ensure the development of the whole community and maximize the competitive advantages of target plants.

Author Contributions: Q.L., H.H. and K.L. designed the study; Q.L., Y.H. and K.C. conducted the sampling; Q.L., Y.H., X.H., K.L. and H.H. conducted the data analyses and wrote the paper. All authors have read and agreed to the published version of the manuscript.

Funding: This research was funded by the National Science Foundation of China (No. 31930074; 31971473).

Institutional Review Board Statement: Not applicable.

Informed Consent Statement: Not applicable.

Data Availability Statement: Data are presented in the text.

Acknowledgments: We are grateful to Jingchen Xue and Rongshu Qian for samples analysis. This study was financially supported by the National Science Foundation of China (No. 31930074; 31971473).

Conflicts of Interest: The authors declare no conflict of interest.

\section{References}

1. Scheffer, M.; Hosper, S.H.; Meijer, M.L.; Moss, B.; Jeppesen, E. Alternative equilibria in shallow lakes. Trends Ecol. Evol. 1993, 8, 275-279. [CrossRef]

2. Jeppesen, E.; Søndergaard, M.; Søndergaard, M.; Christoersen, K. (Eds.) The Structuring Role of Submerged Macrophytes in Lakes; Springer-Verlag New York, Inc.: New York, NY, USA, 1998.

3. Stansfield, J.H.; Perrow, M.R.; Tench, L.D.; Jowitt, A.; Taylor, A. Submerged macrophytes as refuges for grazing Cladocera against fish [-3pt] predation: Observations on seasonal changes in relation to macrophyte cover and predation pressure. Hydrobiologia 1997, 342, 229-240. [CrossRef]

4. Maceina, M.; Bettoli, P.; Klussmann, W.; Betsill, R.K.; Noble, R.L. Effect of aquatic macrophyte removal on recruitment and growth of black crappies and white crappies in Lake Conroe, Texas. N. Am. J. Fish. Manag. 1991, 11, 556-563. [CrossRef] 
5. Moss, B. Engineering and biological approaches to the restoration from eutrophication of shallow lakes in which aquatic plant communities are important components. Hydrobiologia 1990, 200/201, 367-377. [CrossRef]

6. Li, P. Researches on the Relationships between Periphytic Algae, Phytoplankton and Vallisneria natans [Dissertation]. Master's Thesis, Huazhong Agricultural University, Wuhan, China, 2012.

7. Middelboe, A.L.; Markager, S. Depth limits and minimum light requirements of freshwater macrophytes. Freshw. Biol. 1997, 37, 553-568. [CrossRef]

8. Chambers, P.A.; Kaiff, J. Depth distribution and biomass of submersed aquatic macrophyte communities in relation to Secchi depth. Can. J. Fish. Aquat. Sci. 1985, 42, 701-709. [CrossRef]

9. Li, L.; Bonser, S.P.; Lan, Z.; Xu, L.; Chen, J.; Song, Z. Water depth affects reproductive allocation and reproductive allometry in the submerged macrophyte Vallisneria natans. Sci. Rep. 2017, 7, 16842. [CrossRef]

10. Li, L.; Lan, Z.C.; Chen, J.K.; Song, Z.P. Allocation to clonal and sexual reproduction and its plasticity in Vallisneria spinulosa along a water-depth gradient. Ecosphere 2018, 9, e02070. [CrossRef]

11. Beklioglu, M.; Altinayar, G.; Tan, C.O. Water level control over submerged macrophyte development in five shallow lakes of Mediterranean Turkey. Arch. fur Hydrobiol. 2006, 166, 535-556. [CrossRef]

12. Havens, K.E.; Fox, D.; Gornak, S.; Hanlon, C. Aquatic vegetation and largemouth bass population responses to water-level variations in Lake Okeechobee, Florida (USA). Hydrobiologia 2005, 539, 225-237. [CrossRef]

13. Geest, G.; Wolters, H.; Roozen, F.; Coops, H.; Roijacker, R.; Buijse, A. Water-level fluctuations affect macrophyte richness in floodplain lakes. Hydrobiologia 2005, 539, 239-248. [CrossRef]

14. Li, D.H.; Yang, S.; Fang, T.; Liu, J.Y.; Liu, Y.D. Recovery of aquatic macrophytes by use of water level regulation method in eutrophicated lakes-A case study of Wuli Lake, Wuxi city. Environ. Sci. Technol. 2008, 31, 59-62.

15. Yu, J.L.; Liu, Z.W.; Li, K.Y.; Chen, F.Z.; Guan, B.H.; Hu, Y.H.; Zhong, P.; Tang, Y.L.; Zhao, X.F.; He, H.; et al. Restoration of shallow lakes in subtropical and tropical China: Response of nutrients and water clarity to biomanipulation by fish removal and submerged plant transplantation. Water 2016, 8, 438. [CrossRef]

16. Liu, Z.W.; Hu, J.R.; Zhong, P.; Zhang, X.F.; Ning, J.J.; Larsen, S.E.; Chen, D.Y.; Gao, Y.M.; He, H.; Jeppesen, E. Successful restoration of a tropical shallow eutrophic lake: Strong bottom-up but weak top-down effects recorded. Water Res. 2018, 146, 88-97. [CrossRef]

17. Chambers, P.A.; Prepas, E.E. Competition and coexistence in submerged aquatic plant communities: The effects of species interactions versus abiotic factors. Freshw. Biol. 2010, 23, 541-550. [CrossRef]

18. Gao, F.; Zhang, Y.M.; Fei, Y.; Ma, M.J.; Ding, Y.R. Growth and photosynthetic fluorescence characteristics responses of four submersed macrophytes to rising water level. J. Ecol. Rural. Environ. 2017, 33, 341-348. [CrossRef]

19. Ge, F.J.; Liu, B.Y.; Lu, Z.Y.; Gao, Y.N.; Wu, Z.B. Effects of light intensity on growth and phenolic contents of Myriophyllum spicatum. Environ. Sci. Technol. 2012, 35, 30-34. [CrossRef]

20. Liu, W.L.; Hu, W.P.; Chen, Y.G.; Gu, X.H.; Hu, Z.X.; Chen, Y.W.; Ji, J. Temporal and spatial variation of aquatic macrophytes in west Taihu Lake. Acta Ecol. Sin. 2007, 27, 159-170.

21. Jin, X.; Tu, Q. The Standard Methods for Obervation and Analysis in Lake Eutrophication; Environmental Science Press: Beijing, China, 1990. (In Chinese)

22. SEPA. Analytical Methods for Water and Waster Water Monitor, 4th ed.; Chinese Environmental Science Press: Beijing, China, 2002. (In Chinese)

23. Langhans, R.W.; Tibbitts, T.W. Plant Growth Chamber Handbook; Iowa Agriculture and Home Economics Experimental Station: Ames, IA, America, 1997. [CrossRef]

24. Li, Q.S.; Huang, Q.; Li, Y.J.; Han, Y.Q.; Jin, H.; He, H.; Li, K.Y. Effects of water depth on growth of submerged macrophytes Vallisneria natans and Myriophyllum spicatum. J. Lake Sci. 2019, 31, 1045-1054. [CrossRef]

25. Jin, S.; Ibrahim, M.; Muhammad, S.; Khan, S.; Li, G. Light intensity effects on the growth and biomass production of submerged macrophytes in different water strata. Arab. J. Geosci. 2020, 13, 948. [CrossRef]

26. Dong, B.L.; Zhou, Y.Q.; Jeppesen, E.; Shi, K.; Qin, B.Q. Response of community composition and biomass of submerged macrophytes to variation in underwater light, wind and trophic status in a large eutrophic shallow lake. J. Environ. Sci. 2021, 103, 298-310. [CrossRef] [PubMed]

27. Su, W.H.; Zhang, G.F.; Zhang, Y.S.; Xiao, H.; Xia, F. Photosynthetic characteristics of five submerged macrophytes. Acta Hydrobiol. Sin. 2004, 28, 391-395.

28. Diao, R.X.; Xu, Z.A.; Wu, D.H. In situ enclosure study on growth of Vallisneria natans at different water depths in Taihu Lake. J. Hydroecology 2017, 38, 43-47. [CrossRef]

29. Fu, H.; Yuan, G.X.; Cao, T.; Ni, L.Y.; Zhang, X.L. Clonal growth and foraging behavior of a submerged macrophyte Vallisneria natans in response to water depth gradient. J. Lake Sci. 2012, 24, 705-711. [CrossRef]

30. Xiao, K.Y.; Yu, D.; Wu, Z. Differential effects of water depth and sediment type on clonal growth of the submersed macrophyte Vallisneria natans. Hydrobiologia 2007, 589, 265-272. [CrossRef]

31. Gu, Y.F.; Wang, J.; Wang, J.; Fang, G.S.; Han, L. Morphological response and growth strategy of the submerged macrophyte Vallisneria natans under different water depths. J. Lake Sci. 2017, 29, 654-661. [CrossRef]

32. Li, Q.; Wang, G.X. Influence of silts on growth and development of Hydrilla verticillata seeding in silt waters. Acta Ecol. Sin. 2010, 30, 995-1002. 
33. Wu, X.D.; Wang, G.X.; Cheng, Z.Y.; Wei, H.N.; Li, Z.G.; Wang, L.Z. Response of Hydrilla verticillata in growth to water depth gradient. J. Ecol. Rural. Environ. 2011, 27, 40-45.

34. Li, K.Y.; Liu, Z.W.; Wang, C.Z.; Wang, C.H.; Shi, J.D.; Hu, Y.H. Effect of low dissolved oxygen on the growth of Vallisneria spiralis. Resour. Environ. Yangtze Basin 2006, 15, 670-673.

35. Wang, Q.; Zhou, X.D.; Luo, J.H.; Chen, C. Remote sensing monitoring and analysis of dominant species of submerged vegetation in Taihu Lake over last 30 years. Water Resour. Prot. 2016, 32, 123-129. [CrossRef]

36. Xiong, F.; Li, W.C.; Pan, J.Z.; Xia, T.X.; Li, A.Q. Distribution and community structure characteristics of submerged macrophytes in Lake Fuxian, Yunnan Province. Acta Bot. Yunnanica 2006, 28, 277-282.

37. Regmi, T.; Shah, D.N.; Doody, T.M.; Cuddy, S.; Shah, R. Hydrological alteration induced changes on macrophyte community composition in sub-tropical floodplain wetlands of Nepal. Aquat. Bot. 2021, 103413. [CrossRef] 